A N N A L E S

UNIVERSITATIS MARIAE CURIE-SKŁODOWSKA

LUBLIN - POLONIA

VOL. LXVI, 1

SECTIO C

2011

\author{
MARIOLA ANDREJKO ${ }^{1}$, MAGDALENA MIZERSKA-DUDKA ${ }^{2}$ \\ ${ }^{1}$ Department of Invertebrate Immunology, Faculty of Biology and Earth Sciences \\ Maria Curie-Skłodowska University, Akademicka 19, 20-033 Lublin, Poland \\ e-mail:mariola.andrejko@wp.pl \\ ${ }^{2}$ Department of Virology and Immunology, Faculty of Biology and Earth Sciences \\ Maria Curie-Skłodowska University
}

\title{
Analysis of Galleria mellonella hemolymph proteins profile after metalloproteinase immune challenge
}

Analiza profilu białek hemolimfy Galleria mellonella immunizowanych metaloproteazami

\section{SUMMARY}

A comparison of the 2D gels of the metalloproteinase-immunized and control insects showed that elastase B and thermolysin were responsible for changes in the pattern of hemolymph proteins/ peptides of Galleria mellonella larvae. It was found that the amount of apolp-III and lysozyme increased in response to injection of elastase B and thermolysin. Approximately 11 newly synthesized proteins/peptides were detected after metalloproteinase injection. We also observed that certain peptides were up-regulated depending on the metalloproteinases used. Some proteins/peptides which were present in the metalloproteinase-challenged larvae were absent in the hemolymph from the non-treated control larvae. They may be degradation products of hemolymph proteins treated with metalloproteinases.

\section{STRESZCZENIE}

Metodą elektroforezy dwukierunkowej wykazano zmiany w profilu białek i peptydów hemolimfy gąsienic Galleria mellonella immunizowanych elastazą B lub termolizyną. Stwierdzono zwiększoną ilość białka apoLp-III oraz lizozymu po iniekcji metaloproteinaz. W hemolimfie zaobserwowano 11 nowo zsyntetyzowanych białek/peptydów. Wykazano również, że niektóre białka/ peptydy ulegały zwiększonej syntezie w zależności od zastosowanej proteazy. Niektóre białka/peptydy obecne $\mathrm{w}$ hemolimfie gąsienic immunizowanych metaloproteinazą nie występowały w hemolimfie gąsienic kontrolnych. Mogą to być produkty degradacji proteolitycznej białek hemolimfy. 
K e y w or d s: elastase B, Pseudomonas aeruginosa, immune response, Galleria mellonella.

Słow a klu czow e: elastaza B, Pseudomonas aeruginosa, reakcja immunologiczna, Galleria mellonella.

\section{INTRODUCTION}

Metalloproteinases associated with human pathogenic bacteria and fungi have been playing a predominant role as virulence factors during pathogenesis $(19,23)$. They promote development within the infected host and interfere with its immune system $(16,17,22,24,29)$. The therapeutic inhibition of metalloproteinases has become a novel strategy in the development of secondgeneration antibiotics $(27,28)$.

A thermolysin-like metalloproteinase released by the entomopathogenic fungus Metarhizium anisopliae and Beauveria bassiana inhibited phagocytic activity, attachment and spreading of plasmatocytes isolated from larvae of G. mellonella (13). Bacillus thuringiensis produces a metalloproteinase which degrades cecropin of the infected host (11). Recently, studies performed in our laboratory indicated that $P$. aeruginos $a$ elastase B degraded inducible antimicrobial peptides in the hemolymph of G. mellonella (5). In addition, it was shown that elastase B stimulates the innate immune response in the greater wax moth (6).

The recognition system for a microbial pattern in G. mellonella is capable of sensing both microbial cell wall components, such as bacterial LPS, and endogenous immune stimulatory peptides generated by microbial metalloproteinases. The infectious non-self model postulates that the immune system is set into alarm by recognition of microbial pattern molecules which are absent in the host, e.g., microbial cell wall components, whereas the so-called danger model explains the activation of immune response by alarm signals from injured cells, such as those exposed to pathogens, toxins or mechanical damage $(1,21)$.

It was recently reported that the presence and activity of microbial metalloproteinases within the body of G. mellonella results in the formation of small peptides with molecular masses below 3 $\mathrm{kDa}$, which are potent elicitors of innate immune responses (14). Peptidic fragments derived from hemolymph proteins or collagen IV serve as danger signals triggering a set of signalling pathways that lead to the induced expression of immune-related genes $(2,3,4,14)$.

In this study, we examined the changes in the pattern of hemolymph proteins/peptides in the metalloproteinase-challenged G. mellonella larvae.

\section{MATERIAL AND METHODS}

\section{Biological species}

The larvae of greater wax moth G. mellonella (Lepidoptera: Pyralidae) were reared on a natural diet-honeybee nest debris at $30^{\circ} \mathrm{C}$ in the dark. Last instar larvae (250-300 $\mathrm{mg}$ in mass) were selected for this study.

Pseudomonas aeruginosa strain ATCC 27853, the pyocyanin-producing strain, an isolate of moderate virulence to $7^{\text {th }}$ instar larvae of $G$. mellonella $\left(\mathrm{LD}_{50}=17\right.$ cells) were used in this study. The bacterial cells were grown in nutrient broth for $24 \mathrm{~h}$ at $37^{\circ} \mathrm{C}$ and pelleted by centrifugation at $20,000 \mathrm{~g}$ for $10 \mathrm{~min}$ at $4^{\circ} \mathrm{C}$.

\section{Immune challenge}

For immune challenge, the larvae were injected with $0.1 \mu \mathrm{g} /$ larvae of elastase B (enzyme fraction in $10 \mathrm{mM}$ ammonium acetate buffer) or $0.5 \mu \mathrm{g} /$ larvae of thermolysin (Sigma) dissolved 
in Ringer solution (172 mM KCl, $68 \mathrm{mM} \mathrm{NaCl}, 5 \mathrm{mM} \mathrm{NaHCO} 3, \mathrm{pH}$ 6.1). After the treatment, the larvae were kept at $30^{\circ} \mathrm{C}$ in the dark on sterile Petri dishes and the hemolymph was collected after the time indicated in the text.

\section{Hemolymph collection}

Prior to hemolymph collection, the insects were chilled for $15 \mathrm{~min}$ at $4^{\circ} \mathrm{C}$. Hemolymph samples were obtained by puncturing larval abdomen with a sterile needle. The out-flowing hemolymph was immediately transferred into sterile and chilled Eppendorf tubes containing a few crystals of phenylthiourea (PTU) to prevent melanisation. The hemocyte-free hemolymph was obtained by centrifugation at $200 \mathrm{~g}$ for $5 \mathrm{~min}$ and subsequently at $20,000 \mathrm{~g}$ for $10 \mathrm{~min}$ at $4^{\circ} \mathrm{C}$. Pooled supernatants were stored at $-20^{\circ} \mathrm{C}$ until used.

\section{Preparation of acidic/methanol hemolymph extracts}

Low molecular mass proteins and peptides were isolated from hemocyte-free hemolymph by the acidic/methanol extraction method adapted from Schoofs et al (26). The hemolymph was diluted 10 times with the extraction solution consisting of methanol:glacial acetic acid:water (90:1:9) and mixed thoroughly. Precipitated proteins were pelleted by centrifugation at $20,000 \mathrm{~g}$ for $30 \mathrm{~min}$ at $4^{\circ}$ C. The obtained supernatant was collected, vacuum dried and the pellet was stored at $-20^{\circ} \mathrm{C}$ until needed. Before use, it was dissolved in an appropriate volume of sterile distilled water. The acidic/ methanol hemolymph extract obtained as described above contained proteins and peptides of $\mathrm{M}_{\mathrm{r}}$ below $30 \mathrm{kDa}$.

\section{Purification of elastase B}

Elastase B was isolated from $P$. aeruginosa growth medium. The cells were cultivated under aerobic conditions at $38^{\circ} \mathrm{C}$ for $20 \mathrm{~h}$. Then the bacterial culture was centrifuged at $10,000 \mathrm{~g}$ for $60 \mathrm{~min}$ to pellet the cells. Then the supernatant was filtered through a $0.30-\mu \mathrm{m}$-pore-size filter (Millipore) to remove any remaining bacteria. The resulting clear supernatant was used as the starting material. Proteins secreted into the growth medium were precipitated from the filtrate with ammonium sulfate ( $90 \%$ of saturation). The precipitate was collected by centrifugation $(20,000 \mathrm{~g}$, $30 \mathrm{~min}, 4^{\circ} \mathrm{C}$ ), dissolved in $10 \mathrm{mM}$ ammonium acetate buffer ( $\mathrm{pH} \mathrm{6.6)}$ ) and dialysed overnight against the same buffer. The dialysed solution containing $20 \mathrm{mg}$ of protein was fractionated using ionexchange chromatography. As the first step, anion-exchange chromatography on DEAE-cellulose column (DE 52, Whatman) was used. Proteins which did not bind to this resin were immediately fractionated by cation-exchange chromatography on phosphocellulose column (P-11, Whatman). Both columns were equilibrated with $10 \mathrm{mM}$ ammonium acetate buffer. Proteins bound to the P-11 column were eluted with linear $\mathrm{pH}$ 6.6-9.0 gradient of the above buffer. The active fractions were pooled, concentrated on polyethylene glycol 20000 (PEG 20,000, dialysed overnight against $10 \mathrm{mM}$ ammonium acetate buffer ( $\mathrm{pH} 6.6$ ) and stored in the same buffer containing $40 \%$ glycerol at $-20^{\circ} \mathrm{C}$.

\section{Enzyme assay}

The elastolytic activity was determined using a modification of the method by Caballero et al. (9). Elastin congo red $5 \mathrm{mg}$, (ICN Biomedicals Inc. ) in $375 \mu \mathrm{l}$ of $10 \mathrm{mM}$ Tris- $\mathrm{HCl}$ (pH 8.0) with or without $6 \mathrm{mM}$ EDTA was mixed with $5 \mu$ enzyme solution $(0.4 \mu \mathrm{g}$ of protein) in $120 \mu \mathrm{l}$ of the same buffer. The reaction mixture $(500 \mu \mathrm{l})$ was incubated at $37^{\circ} \mathrm{C}$ for $24 \mathrm{~h}$ and centrifuged at $10,000 \mathrm{~g}$ for $15 \mathrm{~min}$ and the absorbance was recorded at $490 \mathrm{~nm}$ using a Smart-Spec TM 3000 (Bio-Rad) spectrophotometer. 


\section{Electrophoresis methods}

Polyacrylamide gel electrophoresis of protein samples was performed by tricine SDS-PAGE $(16.5 \%$ T, 3\% C) according to Schägger and von Jagow (25). Protein bands were visualized by Coomassie Brilliant Blue R-250 staining.

\section{Two-dimensional gel electrophoresis of hemolymph extract proteins}

Two-dimensional gel electrophoresis was performed with $150 \mu \mathrm{g}$ of hemocyte-free hemolymph extract protein using the Protean IEF focusing system (Bio-Rad) according to the manufacturer's recommendations. The sample was suspended in rehydratation buffer $(8.8 \mathrm{~mol} / \mathrm{L}$ urea; $2 \% \mathrm{~W} / \mathrm{V}$, CHAPS; $70 \mathrm{mmol} / \mathrm{L}$ DTT; $0.2 \% \mathrm{~W} / \mathrm{V}$, Bio-Lytes) and loaded on $70 \mathrm{~mm}$ IPG strips (Bio-Rad). After separation of proteins in the first dimension, strips were equilibrated twice for $15 \mathrm{~min}$ in equilibration buffer $(6 \mathrm{~mol} / \mathrm{L}$ urea; $20 \% \mathrm{~V} / \mathrm{V}$, glycerol; $2 \% \mathrm{~W} / \mathrm{V}, \mathrm{SDS} ; 375 \mathrm{mmol} / \mathrm{L}$ Tris- $\mathrm{HCl}, \mathrm{pH}$ 8.8). The first step was done in equilibration buffer with $130 \mathrm{mmol} / \mathrm{L}$ DTT, the second equilibration buffer contained $135 \mathrm{mmol} / \mathrm{L}$ iodoacetamide. Then Tris-Tricine-SDS-PAGE was performed in $16.5 \%$ acrylamide gel under the conditions described above.

\section{The concentration of proteins}

The concentration of proteins was estimated by the Bradford method using bovine serum albumin (BSA) as a standard (7).

\section{RESULTS AND DISCUSSION}

The invertebrate immune response can be activated by danger signals from injured cells such as those exposed to mechanical damage, pathogens or toxins $(21,2)$. The special role in this model is played by microbial metalloproteinases which represent potent activators of innate immunity in insect (12). It is known that injection of bacterial thermolysin at a sublethal concentration into G. mellonella larvae mediates immune response (14). In our experiments, we used elastase B (pseudolysin, LasB), a thermolysin-like neutral zinc-metalloprotease which is an important virulence factor of the opportunistic human pathogen $P$. aeruginosa (Fig. 1).

Two-dimensional gel electrophoresis was employed to investigate the changes in the pattern of hemolymph proteins/peptides after injection of LasB or thermolysin at sublethal concentration. Acidic/methanolic extracts of cell-free hemolymph were used as a source of immune peptides/proteins (MATERIALS AND METHODS). Control hemolymph extract was obtained from the nontreated larvae. Antimicrobial peptides are mainly cationic peptides with molecular masses between 4 and $20 \mathrm{kDa}$. Therefore, in the first dimension we used IPG strips with $\mathrm{pI}$ values ranging from 3 to 11 and in the second dimension $16.5 \%$ Tris-Tricine-SDS-PAGE electrophoresis.

A comparison of the 2D gels of the metalloproteinase-immunized and control insects showed that the protein spot patterns changed greatly after injection. The most abundant protein in the hemolymph extracts was apoLp-III consisting of a few isoforms with a molecular mass of $18 \mathrm{kDa}$ but a different isoelectric point 


\section{Fig.1}

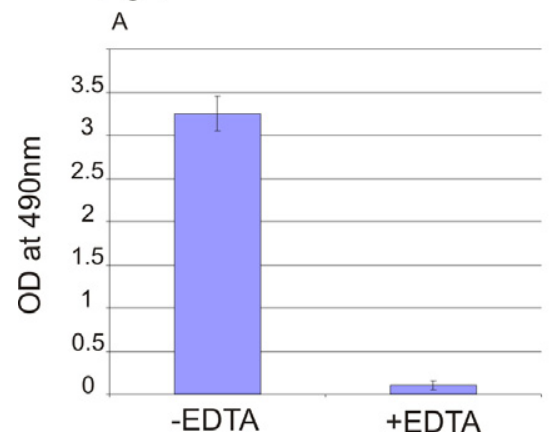

B

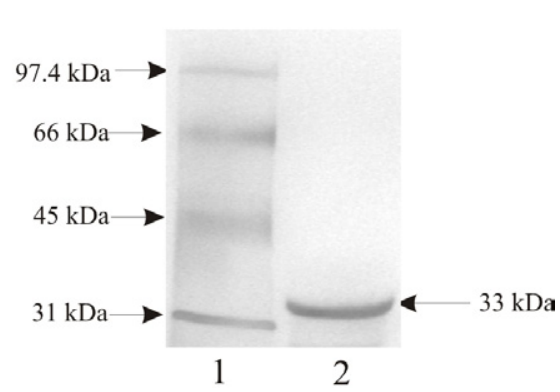

Fig. 1. Identification of elastase B in the culture supernatant of P. aeruginosa. A. Diagram represents proteolytic cleavage of elastin congo red by fraction obtained by ion-exchange chromatography on DEAE-cellulose and P-cellulose alone or in the presence of 6 mM EDTA. B. Proteins in the fraction were visualized by silver staining after glycine SDS-PAGE (lane 2). Low molecular mass standards are presented on lane 1. Each experiment was performed at least three times. Bars represent $\pm \mathrm{SD}$
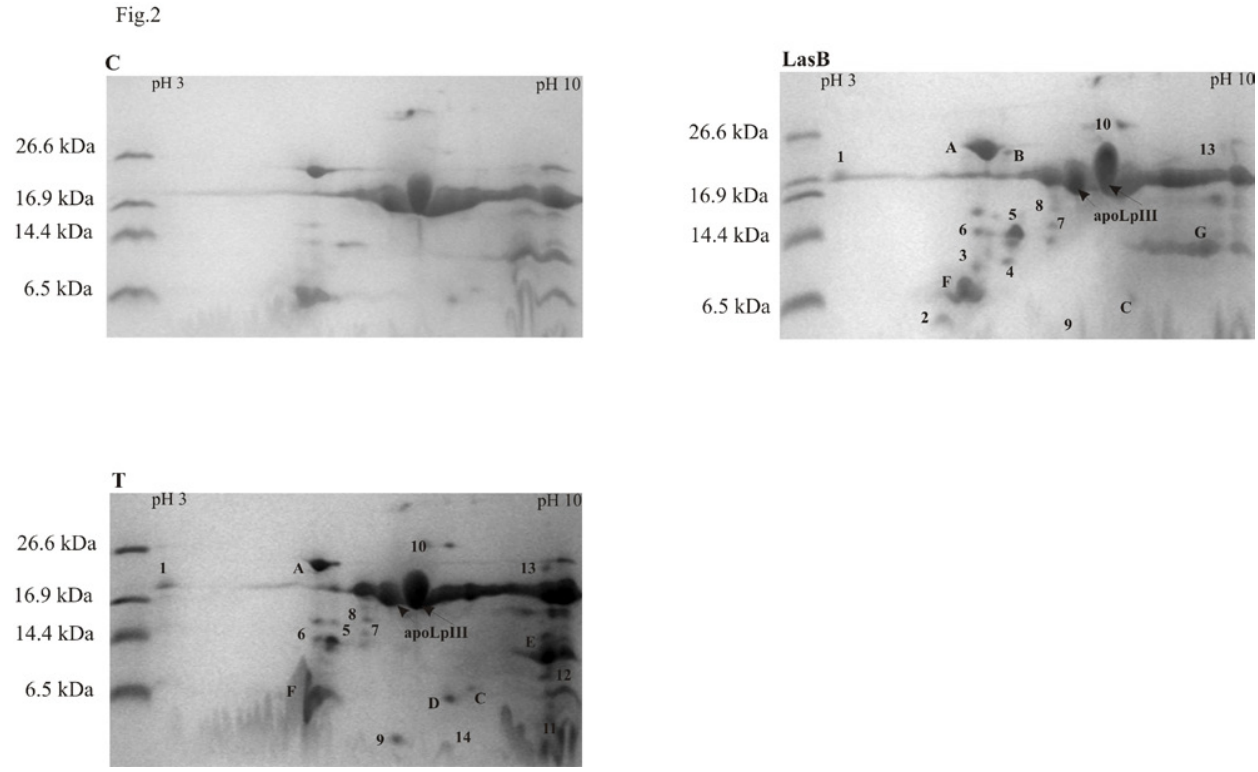

Fig. 2. Two-dimensional analysis of hemolymph extract proteins/peptides from (T) thermolysinchallenged (0.5 $\mu \mathrm{g} /$ larvae), (Las B) LasB-challenged (0.1 $\mu \mathrm{g} /$ larvae) or (C) untreated larvae. The samples $(150 \mu \mathrm{g}$ of protein) were separated according to their isoelectric points on immobilized 3-11 pH-gradients, then separated by $16.5 \%$ Tricine SDS/PAGE. The newly synthetised proteins/ peptides are indicated by numbers (1-14). The differently regulated proteins/peptides are indicated by letters $(A-G)$. Three independent experiments were carried out 
(Fig. 2). It was found that the amount of $18 \mathrm{kDa}$ protein increased in response to injection of elastase B or thermolysin (Fig. 2). These results are in line with our data reported previously (6). It was also shown that immune challenge with Gramnegative and Gram-positive bacteria led to an increase in the level of apolp-III in G. mellonella hemolymph (30).

Approximately 11 newly synthesized proteins/peptides were detected after LasB (spots 1, 10-13) and thermolysin injection (spots 1, 5, 14) (Fig. 10).

Since most of the immune peptides appeared in the $\mathrm{pH}$ range of 4-11, the characteristic peptide with a molecular mass of $18 \mathrm{kDa}$ and $\mathrm{pI} 3$ drew our attention (spot 1 in Fig. 2) in the metalloprotease-immunized larvae. Attacins are a family of proteins, active against Gram-negative bacteria, with a molecular mass in the range $20-23 \mathrm{kDa}(15)$. This peptide could therefore belong to this family.

Among the newly synthesized peptides, we observed a few peptides with a molecular mass below $6.5 \mathrm{kDa}$ which could be induced antimicrobial peptides. According to the literature data, it can be conjectured that these peptides belong to the antimicrobial G. mellonella peptides (10). It is known that G. mellonella can release at least 18 antimicrobial peptides from 10 families to defend itself against invading microbes (8).

Spot 2 (4 kDa, pI 4) was observed after LasB challenge. This seems to be the $\mathrm{Gm}$ anionic peptide (with a molecular mass $4.8 \mathrm{kDa}$, pI 4.51) which exhibited antibacterial activity (Micrococcus luteus, Listeria monocytogenes) and was effective in inhibition of filamentous fungi growth (Aspergillus niger, Trichoderma harzianum) (10).

Upon thermolysin injection (Fig. 2) appearance of an immune peptide with a molecular mass of $4 \mathrm{kDa}$ and $\mathrm{pI} 10$ (spot 11) was observed. This may have been Gm proline-rich peptide 1 characterized by Cytryńska et al. (10), Lee et al. (18) and Mak et al. (20).

The induction of novel peptide with a molecular mass of $4 \mathrm{kDa}$ and $\mathrm{pI} 6$ (spot 9 in Fig. 10) was observed after injection of either LasB or thermolysin. There are at least three different peptides with a molecular mass $4 \mathrm{kDa}$ and $\mathrm{pI} 6$ isolated from immunized G. mellonella larvae, namely: defensin, a defensin-like, and a cecropin D-like peptide (10).

We also observed several differently regulated proteins in the hemolymph of the immunized larvae. It seems that certain peptides were up-regulated depending on the metalloproteinases used. Increased expression of 5 proteins/peptides was observed in the case of LasB injection (spots A, B, C, F , G) as well as in the case of thermolysin in comparison with the control insects (A, C, D, E, F).

The molecular mass $(14 \mathrm{kDa})$ and its isoelectric point (9.3) of spot E in Figure 2 suggested that it was Galleria lysozyme. In this report, the level of lysozyme was greatly increased in the hemolymph thermolysin-challenged larvae. 
Two-dimensional SDS-PAGE analysis of hemolymph samples from larvae injected with sublethal doses of bacterial metalloproteinases revealed changes in expression of a number of proteins associated with the immune response. It should be emphasized that some proteins/peptides which were present in the metalloproteinase-challenged larvae were absent in the hemolymph obtained from the non-treated control larvae. These results indicate that they may be degradation products of hemolymph proteins treated with metalloproteinases.

\section{REFERENCES}

1. Altincicek B., Berisha A., Mukherjee K., Spengler B., Römpp A., Vilcinskas A. 2009. Identification of collagen IV derived danger/alarm signals in insect immunity by nanoLC-FTICR MS. Biol. Chem. 390, 1303-1311.

2. Altincicek B., Linder M., Linder D., Preissner K. T., Vilcinskas A. 2007. Microbial metalloproteinases mediate sensing of invading pathogens and activate innate immune responses in the Lepidopteran model host Galleria mellonella. Infect. Immun. 75, 175-183.

3. Altincicek B., Vilcinskas A. 2006. Metamorphosis and collagen-IV-fragments stimulate innate immune response in the greater wax moth, Galleria mellonella. Dev. Comp. Immunol. 30, $1108-1118$.

4. Altincicek B., Vilcinskas A. 2008. Identification of a lepidopteran matrix metalloproteinase with dual roles in metamorphosis and innate immunity. Dev. Comp. Immunol. 32, 400-409.

5. Andrejko M., Mizerska-Dudka M., Jakubowicz T. 2009. Antibacterial activity in vivo and in vitro in the hemolymph of Galleria mellonella infected with Pseudomonas aeruginosa. Comp. Biochem. Physiol. 152, 118-123.

6. Andrejko M., Mizerska-Dudka M. 2011. Elastase B Pseudomonas aeruginosa stimulates the innate immune response in the greater wax moth Galleria mellonella. J. Invert. Pathol. 107, $16-26$.

7. Bradford M. M. 1976. A rapid and sensitive method for quantitation of microgram quantities of protein utilizing the principle of protein-dye binding. Anal. Biochem.72, 248-410.

8. Brown S. E., Howard A., Kasprzak A. B., Gordon K. H., East P. D. 2009. A peptidomic study reveals the impressive antimicrobial peptide arsenal of the wax moth Galleria mellonella. Insect Biochem. Mol. Biol. 39, 792-800.

9. Caballero A. R., Moreau J. M., Engel L. S., Marquart M. E., Hill J. M., O’Callaghan R. J., 2001. Pseudomonas aeruginosa protease IV enzyme assays and comparison to other Pseudomonas proteases. Anal. Biochem. 290, 330-337.

10. Cytryńska M., Mak P., Zdybicka-Barabas A., Suder P., Jakubowicz T., 2007. Purification and characterization of eight peptides from Galleria mellonella immune hemolymph. Peptides 28, 533-546.

11. Dalhammar G., Steiner H. 1984. Characterization of inhibitor A, a protease from Bacillus thuringiensis which degrades attacins and cecropins, two classes of antibacterial proteins in insects. Eur. J. Biochem. 139, 247-252.

12. Gillespie J. P., Bailey A. M., Cobb B., Vilcinskas A. 2000. Fungi as elicitors of insect immune responses. Arch. Insect Biochem. Physiol. 44, 49-68.

13. Griesch J., Vilcinskas A., 1998. Proteases released by entomopathogenic fungi impair phagocytic activity, attachment and spreading of plasmatocytes isolated from haemolymph of the greater wax moth Galleria mellonella. Biocontrol. Sci. Technol. 8, 517-531. 
14. Griesch J., Wedde M., Vilcinskas A., 2000. Recognition and regulation of metalloproteinase activity in the haemolymph of Galleria mellonella: a new pathway mediating induction of humoral immune responses. Insect Biochem. Mol. Biol. 30, 461-472.

15. Hultmark D., Engström Å., Andersson K., Steine H., Bennich H., Boman H. G. 1983. Insect immunity. Attacins, a family of antibacterial proteins from Hyalophora cecropia. EMBO J. 2, 571-576.

16. Hung C.-Y., Seshan K., Yu J. J., Schaller R., Xue J., Basrur V., Gardner M., Cole G. 2005. A metalloproteinase of Coccidioides posadasii contributes to evasion of host detection. Infect. Immun. 73, 6689-6703.

17. Jin F., Matsushita O., Katayama S.-I., Jin S., Matsushita C., Minami J., Okaże A. 1996. Purification, characterization, and primary structure of Clostridium perfringens lambda-toxin, a thermolysin-like metalloprotease. Infect. Immun. 64, 230-237.

18. Lee Y. S., Yun E. K., Jang W. S., Kim I., Lee J. H., Park S. Y., Ryu K. S., Seo S. J., Kim C. H., Lee I. H. 2004. Purification, cDNA cloning and expression of an insect defensin from the great wax moth, Galleria mellonella. Insect Mol. Biol. 13, 65-72.

19. Maeda H. 1996. Role of metalloproteinases in pathogenesis. Microbiol. Immunol. 40, 685-699.

20. Mak P., Chmiel D., Gacek G. J. 2001. Antibacterial peptides of the moth Galleria mellonella. Acta Biochim. Pol. 48, 1191-1195.

21. Matzinger P. 2002. The danger model: a renewed sense of self. Science 296, 301-305.

22. Miyoshi S.-I., Nakazawa H., Kawata K., Tomochika K. I., Tobe K., Shinoda S. 1998. Characterization of the hemorrhagic reaction caused by Vibrio vulnificus metalloproteinase, a member of the thermolysin family. Infect. Immun. 66, 4851-4855.

23. Miyoshi S., Shinoda S. 2000. Microbial metalloproteasses and pathogenesis. Microbes Infect. 2, 91-98.

24. Miyoshi S.-I., Sonoda Y., Wakiyama H., Rahman M., Tomochika K., Shinoda S., Yamamoto S., Tobe K. 2002. An exocellular thermolysin-like metalloproteinase produced by Vibrio fluvialis: purification, characterization, and gene cloning. Microb. Pathol. 33, 127-134.

25. Schägger H., von Jagow G. 1987. Tricine-sodium dodecyl sulfate-polyacrylamide gel electrophoresis for the separation of proteins in the range 1 to $100 \mathrm{kDa}$. Anal. Biochem. 166, 368-379.

26. Schoofs L., Holman G. M., Nachman R. J., De Loof A., 1990. Locusta tachykinin I and II, two novel insect neuropeptides with homology to peptides from the vertebrate tachykinin family. FEBS Lett. 261, 397-401.

27. Supuran C., Scozzafava A., Mastrolorenzo A. 2001. Bacterial proteases: current therapeutic use and future prospects for the development of new antibiotics. Expert Opin. Ther. Patents 11, 221-259.

28. Travis J., Potempa J. 2000. Bacterial proteinases as targets for development of second-generation antibiotics. Biochim. Biophys. Acta 1477, 35-50.

29. Vilcinskas A., Wedde M., 2002. Insect inhibitors of metalloproteinases. IUBMB Life 54, 339-343.

30. Zdybicka-Barabas A., Cytryńska A., 2011. Involvement of apolipophorin III in antibacterial defense of Galleria mellonella larvae. Comp. Biochem. Physiol. 158, 90-98. 